time, fewer scientists went to the Antarctic. The scientists just didn't see that without this rebuilding programme there would be no science."

In 1984, the Antarctic Division leased a West German supply vessel, the Icebird. "With the addition of the Icebird, we tripled the number of scientists going to the Antarctic. Now we have a new marine research vessel, the Aurora Australis, with the capacity to carry 20 scientists and 20 support staff. Despite this increase in our shipping capacity, there is still this ethos amongst scientists that the rebuilding project is detracting from the science."

Many scientists are unconvinced, waiting

\title{
Helping the local population
}

\section{Davis}

IN June last year, a petroleum spill of 90,000 litres occurred at the Australian station, Casey. An estimated 40,000 litres remains unrecovered. A further 19,000 litres was spilt there in January this year. Biodegradation of these sites through natural microbial activity is hampered by severe cold and a lack of nutrients. Estimates for the time needed for complete removal of such spills in the Antarctic range up to 600 years, compared with a mere 40 years in the more temperate climate of the Arctic. Research at the neighbouring Davis station, however, has shown that the addition of fertilizer can markedly speed up the breakdown of hydrocarbons by bacteria and fungi.

Since 1988, Elizabeth Kerry of the department of agricultural science at the University of Tasmania, has been conducting small controlled petroleum spills on land near Davis station. Sixteen litres of distillate was deposited in four plots in 1988. This was followed by further spills in 25 plots in the 1989-90 summer, to test the effects of fertilizers and increased water availability on the rate of petroleum breakdown. This summer, Kerry returned to take samples to determine the total content of hydrocarbons and the microbial populations in the soil.

In two years, evaporation has removed 28 per cent of compounds of low molecular weight, up to carbon-12. However, to remove the heavier compounds, help is needed. "To get rid of these heavy compounds needs bacteria and fungi. Most hydrocarbon decomposing microbes work

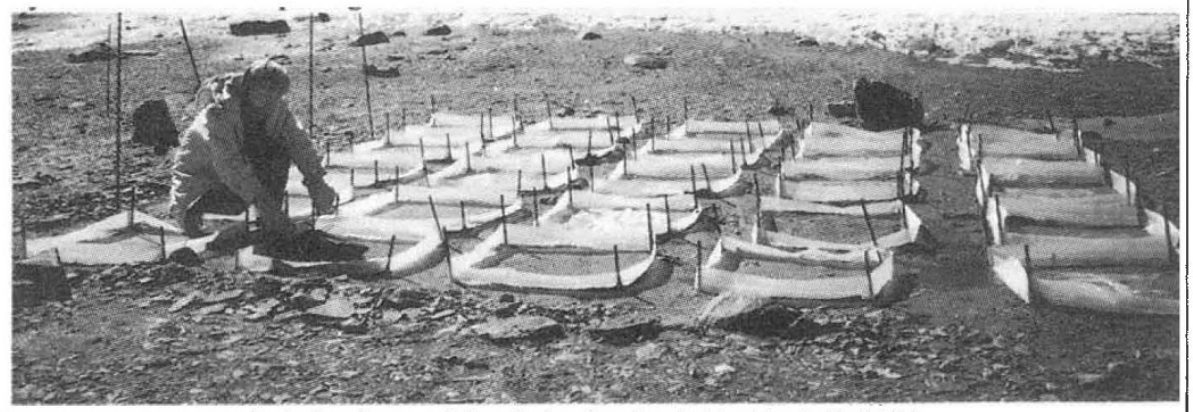

Twenty-five plots of limited oil spillage, wih local microbes tended by tlizabeth Kerry.

best at 25 to $37^{\circ} \mathrm{C}$. Although isolates (of bacteria and fungi) from Davis have been shown to be active at $0^{\circ} \mathrm{C}$, the low temperatures, low water availability and low nutrients all slow down the degradation process", Kerry said.

Initial results from this summer's sampling have shown that the addition of phosphorus and nitrogen to the spills has enhanced degradation almost threefold. Microbial activity in the fertilized soils was also three times that of unfertilized soils.

Spills elsewhere in the world have been 'seeded' with selected hydrocarbon decomposing bacteria (see Nature 349, 447; 1991). However, according to Kerry, in more temperate climates such seeding may be unnecessary. "The required range of microorganisms is likely to be present anyway, either having been introduced with the oil or present in the natural environment."

This range of bacteria and fungi is unlikely to be present in the Antartic. "Antarctica has a more limited microflora and any microorganisms introduced with the oil may not survive the severe climatic conditions."

Part of Kerry's work is to determine if there are enough microorganisms in Antarctic oil spills to degrade a range of petroleum components. But if 'deficiencies' are found, it is unlikely that the introduction of new species of bacteria and fungi would be permitted under Antarctic Treaty restrictions. "New species might become established in natural ecosystems and upset their balance. We would rather learn how to encourage the activity of microbes already present through nutrient enhancement."

T.E.

\section{Warming on the shelf}

\section{Lambert Glacier, near Mawson}

LOCAL warming has caused melt streams in the world's largest glacier to expand by 20 $\mathrm{km}$ in the past two years and to create lakes, $10 \mathrm{~km}$ in length, where none existed three years ago.

During the 1970 s and early 1980 s, the International Glaciological Project, involving the Soviet Union, United States, Britain, France, Australia and Japan measured the velocity and dynamics of around 3 million square kilometres of the East Antarctic ice sheet (between $160^{\circ}$ and $90^{\circ} \mathrm{E}$ ). But at present, Australia is the only nation conducting long-term systematic studies of the glaciology of the East Antarctic ice sheet.

A similar project for the Lambert Glacier and the Amery Ice Shelf ( $300 \mathrm{~km}$ southeast of Mawson) has been planned by Dr Ian Allison, principal researcher in glaciology at the Antarctic Division, since the mid-1970s. The Lambert-Amery traverse aims to skirt the Lambert Glacier on the 2,500-metre contour line.

This summer, $1,250 \mathrm{~km}$ of the traverse was covered. Six men travelled in three turbocharged tractors. Each tractor, pulling a 7080 tonne load, represented home to these men for four months.

Every $30 \mathrm{~km}$, the party would record the satellite position of a marker placed in the snow. These markers will be re-measured in two years, providing information on the velocity of the glacier. A $100-\mathrm{MHz}$ pulse radar with a 5-kW signal continually recorded the thickness of the ice. Poles placed in the snow every $2 \mathrm{~km}$ were measured on the party's return for snow accumulation rates.

In 1992-93 another party, rather than returning to Mawson, will continue to traverse the additional $1,500 \mathrm{~km}$ around to Davis.

According to Allison, while the rate at which the Lambert Glacier is moving has changed little, the melt rates are much higher than expected. "The Lambert is moving at a velocity not much different to 22 years ago and the surface elevation hasn't increased. But there is significant surface melt at the seaward end of the glacier at an elevation of 100 metres. Lakes up to $10 \mathrm{~km}$ in length have appeared in two years and the melt streams have extended $20 \mathrm{~km}$ down the glacier."

Allison believes the increased melt is due to warmer summers in East Antarctica combined with a feedback response. "Snow reflects 80 per cent of sunlight. Melted water reflects only 20 per cent. Sunlight is absorbed and adds to the melting process."

Allison stresses that this glacial melting is not necessarily related to global warming. "This is an indication of local warming over a couple of years. The actual mass balance of the glacier may not have been affected. There may be more snow falling inland which makes up for the melt."

T.E. 